\title{
Pelatihan Manajemen Emosi Sebagai Program Pemulihan Depresi pada Remaja Korban Gempa Bumi
}

\section{Emotion Management Training as Depression Recovery Program for Adolescent Earthquake Survivors}

\author{
Zarina Akbar* \\ Tina Afiatin \\ Fakultas Psikologi UGM Yogyakarta \\ Diterima 20 April 2009 / Disetujui 20 Mei 2009
}

\begin{abstract}
Yogyakarta's earthquake survivors often show depression symptoms. This study is aimed to recognize the effectiveness of emotional management training on mitigating depressed adolescents of Yogyakarta's earthquake survivors. Twenty participants enrolled within, which are categorized into experiment and control group. The participant's characteristics were: second year in junior high school, survivors of Yogyakarta's earthquake, age ranging from 13 to 15. The hypotheses sugaest that emotional management training is effective to decrease depression among adolescents of Yogyakarta's earthquake victim. Beck Depression Inventory was conducted before, after, and at the follow-up to measure depression. Result shows that emotional management training is effective in decreasing depression among adolescents of Yogyakarta's earthquake survivors. Qualitative analysis found that individuals which shows higher hate of declining depression score have different emotion management process compared to the lower. It suggested to next research to focus continously to improve the effectiveness of the training.
\end{abstract}

Keywords: Yogyakarta's earthquake survivors, Emotion Management Training, Depression

Gempa tektonik berkekuatan 5,9 skala richter yang mengguncang wilayah Yogyakarta, Jawa Tengah dan sekitarnya pada tanggal 27 Mei 2006 telah menimbulkan banyak korban jiwa, kerusakan material yang tidak sedikit, dan mempengaruhi kondisi psikologis pada masyarakat korban gempa yang selamat (survivors).

Pengalaman traumatik berupa bencana yang menimbulkan keadaan luka atau cacat fisik, kehilangan keluarga atau orang-orang terdekat, serta musnahnya harta benda dalam waktu sekejap akan menimbulkan gangguan psikologis bagi korban yang selamat. Andrews, Harris, \& Howle (2005) menyatakan bahwa pengalaman traumatik dapat menyebabkan

*Penulis Korespondensi :

Telp. (0274) 550435 HP. 081227504 Email : afiatin04@ugm.ac.id 
munculnya beberapa dampak secara psikologis yang parah dan bersifat kronis. Hal ini juga didukung oleh pendapat dari Rayburn, Wenzel, Elliott, Hambarsoomians, Marshall, \& Tucker (2005) yang menyatakan bahwa pengalaman traumatik dapat menyebabkan terjadinya kondisi mental yang negatif (negative mental health) bagi para korban yang selamat. Untuk itu, penanganan pasca bencana gempa bumi sebagai upaya langsung untuk membantu dan menolong para korban yang selamat perlu segera dilakukan, karena bila tidak tertangani dengan baik individu dapat mengembangkan gangguan kejiwaan yang menyebabkan kesulitan dalam melakukan fungsi dan aktivitas normal. Hal ini pada akhirnya akan dapat berdampak pada individu itu sendiri, keluarga, maupun pada masyarakat sekitarnya.

Suatu keadaan atau kejadian dalam kehidupan yang dinilai menekan, terjadi secara tiba-tiba, dan menimbulkan banyak perubahan seketika seperti bencana gempa bumi akan mengganggu keseimbangan psikologis individu. Individu yang belum dapat menerima kenyataan akan cenderung mengalami stres, dan stres yang berkepanjangan akan menyebabkan munculnya depresi.

Depresi merupakan gangguan suasana hati $(\mathrm{mood})$ berupa perasaan negatif di mana penderita merasa tertekan, putus asa, merasa bersalah, tidak berharga, tidak mempunyai harapan, tidak bergairah, apatis, dan mengalami kesedihan mendalam yang berlangsung lama, serta ditandai dengan gejala-gejala dan tanda-tanda spesifik yang secara substansial menganggu kewajaran tindakan dan perilaku seseorang sehingga penderita tidak dapat berfungsi secara adekuat (Beck, 1985; Lindsay \& Powell, 1994).

Kerentanan terhadap gangguan suasana hati diasumsikan bervariasi sesuai dengan usia, namun pada kenyataannya kelompok yang paling rentan adalah kelompok usia muda. $\mathrm{Hal}$ ini didukung oleh penelitian yang dilakukan oleh Silvia, Newman, Moffit, \& Caspi (1996) yang menyatakan bahwa kelompok remaja memiliki kerentanan yang relatif tinggi untuk mengalami kecenderungan depresi.

Berdasarkan hasil studi pendahuluan yang telah dilakukan di salah satu sekolah yang akan menjadi tempat penelitian, ditemukan bahwa sebagian besar siswa memiliki simtom depresi dalam dirinya. Selain itu, para siswa memiliki kebutuhan emosi yang besar dalam dirinya untuk dapat mengelola emosi yang dirasakan terutama dalam mengelola emosi-emosi negatif yang muncul, mengekspresikan emosi secara tepat, dan mengatasi masalah motivasional yang mengarah pada penurunan tingkah laku tertentu. Berdasarkan fakta tersebut, pendekatan emosi yang lebih menekankan pada proses-proses pengelolaan emosional-motivasional dinilai paling tepat untuk mengatasi simtom-simtom depresi pada proses pemulihan terhadap siswa-siswa sekolah yang menjadi korban gempa bumi. 
Intervensi klinis untuk mengatasi depresi dengan menggunakan pendekatan emosional antara lain melalui terapi humanistik (Terpusat pada klien [client centered] atau terapi proses-pengalaman [process experiential therapy]) dan terapi yang fokus pada emosi (emotion focused therapy). Greenberg dan Watson (1998) menemukan bahwa terapi humanistik efektif dalam mengatasi depresi (Watson, Gordon, Stermac, Kalogerakos, \& Steckley, 2003). Hal ini didukung oleh Goldman, Pos, Greenberg, \& Korman (2003) yang menemukan bahwa terapi proses-pengalaman efektif untuk menurunkan simtom-simtom depresi dan dapat meningkatkan harga diri (self esteem) individu. Selain itu keterampilan mengelola emosi individu meningkat selama proses pelaksanaan intervensi tersebut.

Program intervensi yang lebih menekankan pada aspek emosional ini merupakan suatu program yang selanjutnya akan disebut sebagai program manajemen emosi. Manajemen emosi yang dimaksud dalam penelitian ini merupakan suatu kemampuan mengelola emosi-emosi negatif maladaptif yang dialami individu untuk mencapai emosi yang bersifat lebih adaptif dengan menggunakan beberapa keterampilan emosi antara lain mengenali, mengekspresikan, melepaskan emosi, dan mengurangi emosi negatif yang muncul dalam diri individu serta memperbesar munculnya emosi positif dalam dirinya. Program manajemen emosi ini akan diberikan dalam bentuk pendekatan kelompok.

Program-program manajemen emosi yang pernah dilakukan dengan menggunakan pendekatan kelompok antara lain pelatihan manajemen emosi pada petugas pemadam kebakaran (Scott \& Myers, 2002), program manajemen emosi dalam meningkatkan stabilitas emosi dan hubungan interpersonal pada siswa-siswa SMK (Yang \& Wang, 2001), pelatihan keterampilan regulasi emosi dan interpersonal pada korban PTSD (Cloitre, Cohen, Koenen, \& Han, 2002), serta pelatihan regulasi emosi dalam mengatasi gangguan kecemasan umum (generalized anxiety disorder) (Heimberg, Mennin, Turk, \& Fresco, 2002).

Program-program manajemen emosi yang dilakukan untuk mengatasi gangguan depresi (Horowitz dan Garber, 2006) antara lain dengan menggunakan teknik pemantauan suasana hati (mood monitoring), dengan pelatihan meningkatkan ekspresi emosi, dan melalui pelatihan ekspresi emosi. Program-program manajemen emosi untuk mengatasi depresi di atas hanya menekankan pada salah satu keterampilan emosi saja, misalnya keterampilan mengenal atau mengekspresikan emosi. Program manajemen emosi tampaknya belum pernah dilakukan.

Program manajemen emosi yang memasukkan berbagai macam keterampilan emosi diharapkan dapat membantu menurunkan simtom-simtom depresi yang muncul pada remaja pasca gempa bumi. Stresor yang dialami oleh individu berupa peristiwa bencana gempa bumi 
menimbulkan banyak kehilangan dan perubahan-perubahan dalam kehidupannya. Ketidaksesuaian antara harapan dengan kenyataan memunculkan emosi-emosi negatif pada diri individu antara lain emosi sedih, kecewa, takut, marah, dan putus asa. Pengalamanpengalaman emosional negatif pasca kejadian bencana (emotional disaster) tersebut cenderung tidak dilambangkan atau tidak dimunculkan oleh individu dalam kesadaran karena dipengaruhi oleh strategi mengatasi masalah (coping) yang tidak efektif. Hal ini pada akhirnya menyebabkan munculnya simtom-simtom depresi. Manifestasinya adalah dalam bentuk perilaku-perilaku penurunan motivasional. Berbagai keterampilan emosi diperlukan untuk mengubah keadaan ini menjadi emosi yang lebih bersifat adaptif. Emosi adaptif akan meningkatkan kesejahteraan psikologis ( $p$ sychological well being) individu dan pada akhirnya dapat mengatasi simtom-simtom depresi yang muncul. Hal ini dapat digambarkan sebagai berikut:

Gambar 1:

Dinamika Psikologis Stresor, Pelatihan Manajemen Emosi, dan Penurunan Depresi Pada Remaja Korban Gempa Bumi Yogyakarta

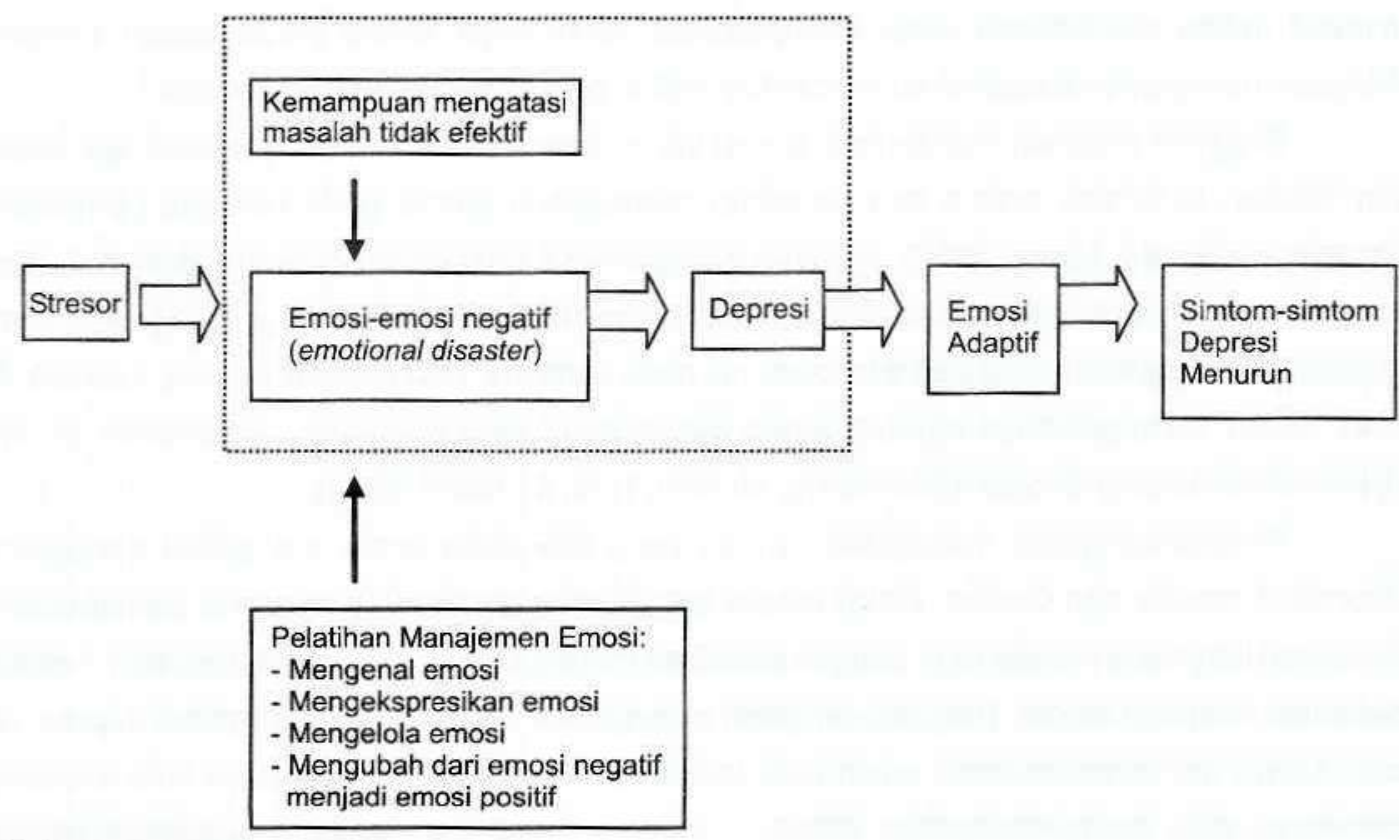

Keterangan:

$\square$ :Menyebabkan atau menimbulkan

:Mempengaruhi
:Area yang dikenai intervensi 
Berdasarkan kerangka berpikir tersebut, penulis tertarik untuk meneliti dan mengetahui apakah simtom-simtom depresi pada remaja yang muncul pada proses pemulihan pasca gempa bumi ini dapat dikurangi dengan program manajemen emosi? Peneliti menggunakan analisis kuantitatif untuk menjawab pertanyaan penelitian tersebut.

Hipotesis yang diajukan adalah pelatihan manajemen emosi efektif untuk mengurangi depresi pada remaja korban selamat gempa bumi Yogyakarta.

Selain pertanyaan penelitian di atas, peneliti juga ingin mengetahui: (1) Apakah pelatihan manajemen emosi efektif dalam mengurangi simtom-simtom depresi; (2) Prosesproses manajemen emosi yang seperti apakah yang dapat mengurangi simtom-simtom depresi?; (3) Proses-proses manajemen emosi yang seperti apakah yang cenderung meningkatkan atau mempertahankan simtom-simtom depresi?; (4) Faktor-faktor apa saja yang dapat menyebabkan munculnya perbedaan itu? Peneliti menggunakan analisis kualitatif untukmenjawab pertanyaan-pertanyaan penelitian tersebut.

\section{Metode Penelitian}

\section{Partisipan}

Partisipan dalam penelitian ini adalah 20 orang siswa SMPN 2 Piyungan, Bantul, Yogyakarta. Partisipan penelitian ini adalah siswa kelas dua dengan rentang usia 13-15 tahun. Karakteristik partisipan dalam penelitian ini adalah siswa-siswa yang menjadi korban selamat gempa bumi Yogyakarta (hal ini didukung oleh data yang menyatakan mengenai keadaan rumah dan keadaan anggota keluarga pasca gempa bumi), memiliki angka hasil tes $\mathrm{BDI}$ (Beck Depression Inventory) yang termasuk kategori sedang, serta memiliki kemampuan manajemen emosi yang rendah (hal ini berdasarkan angket manajemen emosi).

Partisipan penelitian yang terbagi dalam kelompok eksperimen dan kelompok kontrol ditinjau dari jenis kelamin (laki-laki berjumlah 10 orang dan perempuan berjumlah 10 orang), dan usia (usia 13 tahun berjumlah 12 orang, usia 14 tahun berjumlah 6 orang, usia 15 tahun berjumlah dua orang).

\section{Rancangan Penelitian}

Penelitian ini merupakan penelitian kuasi eksperimen (quasi-experiment research), dengan variabel bebas berupa Pelatihan Manajemen Emosi, variabel tergantung berupa tingkat depresi, serta variabel kontrol berupa usia dan pendidikan.

Desain eksperimen yang digunakan adalah desain kelompok kontrol prates-pascates non-random (non-randomized pretest-posttest control group design). Bagan desain 
penelitiannya sebagai berikut:

Tabel 1. Desain Penelitian

\begin{tabular}{ccccc}
\hline Kelompok & Prates & Perlakuan & Pascates & Tindak lanjut \\
\hline KE & Y1 & $\mathrm{X}$ & $\mathrm{Y} 2$ & $\mathrm{Y} 3$ \\
$\mathrm{KK}$ & $\mathrm{Y} 1$ & $\sim \mathrm{X}$ & $\mathrm{Y} 2$ & $\mathrm{Y3}$ \\
\hline
\end{tabular}

Keterangan:

Y1 : Pengukuran prates

Y2 : Pengukuran pascates

Y3 : Pengukuran lanjutan (follow-up)

$X \quad$ : Perlakuan (Pelatihan Manajemen Emosi)

$\sim$ : Tidak diberikan perlakuan (kelompok kontrol)

$\mathrm{KE}$ : KelompokEksperimen

KK : Kelompok Kontrol

\section{Pengumpulan Data}

Untuk memperoleh data yang akan dianalisis secara kuantitatif, alat ukur yang digunakan dalam penelitian ini adalah: BDI (Beck Depression Inventory) dan Skala Manajemen Emosi. Data untuk analisis kualitatif diperoleh berdasarkan hasil observasi, wawancara yang dilakukan terhadap partisipan, data pemantauan diri partisipan dalam kelompok eksperimen selama mengikuti pelatihan manajemen emosi, data lembar-lembar kerja yang diberikan, analisis isi dari buku harian, dan data evaluasi partisipan setelah mengikuti pelatihan manajemen emosi.

BDI (Beck Depression Inventory). Pada penelitian ini, BDI (Beck Depression Inventory) diadaptasi untuk digunakan adalah sebagai alat untuk mengungkap depresi. Beck Depression Inventory (BDI) merupakan self-inventory yang terdiri dari 21 item yang masingmasing berisi empat sampai enam pernyataan yang merupakan respon pilihan bagi subjek. Tiap-tiap pernyataan dalam setiap item diberi skor 1, 2, 3. Item-item dengan pernyataan pararel misal 1a dan 1b, 2a dan 2b,3a dan $3 b$ diberi skor yang sama. Subjek boleh memilih lebih dari satu jawaban namun skor yang diambil adalah yang tertinggi. Skor responden adalah total jumlah jawaban yang menunjukkan berbagai tingkat depresi yaitu tidak depresi, depresi ringan, depresi sedang, dan depresi berat. Semakin besar skor yang diperoleh subjek berarti semakin tinggi tingkat depresinya.

Skala Manajemen Emosi. Skala ini digunakan untuk mengungkap kemampuan awal individu dalam hal manajemen emosi. Aspek-aspek yang diungkap merupakan keterampilanketerampilan dalam manajemen emosi antara lain aspek mengenal emosi, aspek mengekspresikan emosi, aspek mengelola emosi, dan aspek mengubah dari emosi negatif menjadi emosi positif (Greenberg \& Stone, 1992). Skala ini terdiri dari 25 pernyataan. 


\section{Intervensi}

Intervensi yang diberikan pada kelompok eksperimen berupa program pelatihan manajemen emosi bagi para remaja yang menjadi korban selamat gempa bumi Yogyakarta. Program manajemen emosi merupakan suatu program pelatihan yang disusun dari beberapa keterampilan emosi, yang dilaksanakan dalam bentuk pendekatan kelompok. Setelah pemberian intervensi, diharapkan para partisipan dapat mengelola emosi yang muncul pasca peristiwa traumatik bencana gempa bumi, menjadi emosi yang lebih adaptif.

Materi. Materi dalam program pelatihan manajemen emosi meliputi membangun kohesivitas kelompok, melatih keterampilan mengenal emosi, melatih keterampilan mengekspresikan emosi baik secara lisan maupun tulisan, melatih keterampilan mengelola emosi, menjelaskan hubungan antara emosi yang dirasakan dengan perilaku yang dimunculkan, dan melatih keterampilan mengubah emosi negatif menjadi emosi positif. Program manajemen emosi ini dipandu oleh fasilitator, ko-fasilitator, dan pengamat (observer).

Prosedur Penelitian. Penelitian ini dilakukan dalam beberapa tahapan:

1. Persiapan penelitian yaitu:

a. Melakukan studi pendahuluan terhadap seluruh siswa kelas dua SMP N 2 Piyungan. Dari hasil asesmen kebutuhan ditemukan adanya gangguan depresi pada remaja korban selamat gempa bumi Yogyakarta yang lebih mengarah pada simtom-simtom emosional dan motivasional. Pendekatan yang dipilih adalah integrasi dari terapi proses-pengalaman dan terapi yang berfokus pada emosi untuk lebih menekankan pada proses emosi-motivasional dalam mengatasi gangguan depresi. Program manajemen emosi ini dirancang secara khusus untuk mengatasi gangguan depresi tersebut

b. Melatih fasilitator, ko-fasilitator, dan pengamat (observer) yang terlibat dalam pelatihan. Kualifikasi fasilitator dalam memandu pelatihan ini yaitu pernah mengikuti kegiatan pendampingan pasca gempa bumi Yogyakarta, pernah mengikuti kegiatan terapi kelompok, memiliki kemampuan interpersonal yang baik, dan memiliki beberapa kualifikasi keterampilan sebagai konselor antara lain hangat, penuh penerimaan, dan empatik.

c. Menyusun angket manajemen emosi. Peneliti melakukan seleksi partisipan untuk menentukan partisipan yang akan terlibat dalam pelatihan dengan berpedoman pada kriteria partisipan penelitian yang telah ditentukan sebelumnya.

d. Melakukan wawancara semi-terstruktur kepada 20 orang siswa yang terpilih. 
Wawancara tersebut bertujuan untuk mengungkap pengalaman subjek yang berkaitan dengan kejadian gempa yang dialaminya, khususnya berkaitan dengan pengalaman-pengalaman emosional yang dirasakannya.

2. Pelatihan manajemen emosi dilaksanakan sebanyak delapan sesi. Pada setiap minggu dilaksanakan dua sesi, sehingga total waktu yang diperlukan dalam melaksanakan program ini selama satu bulan. Masing-masing pertemuan dilakukan selama dua jam dan satu pertemuan dilakukan selama satu jam, sehingga total waktu yang diperlukan dalam melaksanakan program manajemen emosi adalah $15 \mathrm{jam}$. Jadwal pelaksanaan pelatihan manajemen emosi dari tanggal 2 Agustus - 20 Agustus 2007. Setelah sesi 8 pelatihan manajemen emosi selesai dilakukan, partisipan diberikan lembar evaluasi pelatihan dan langsung dilakukan pascates dengan memberikan BDI (Beck Depression Inventory). Hal ini dilakukan untuk melihat efektivitas pemberian pelatihan manajemen emosi terhadap depresi para remaja yang menjadi korban selamat gempa bumi Yogyakarta.

3. Tahap akhir berupa pelaksanaan tindak lanjut (follow-up) yang dilakukan dua minggu setelah pelaksanaan pascates yaitu pada tanggal 3 September 2007. Pelaksanaan tindak lanjut dilakukan dengan memberikan BDI kepada partisipan dan melakukan wawancara individual. Wawancara individual bertujuan untuk melihat sejauh mana pengaruh pelatihan pada diri masing-masing partisipan dan penerapannya dalam kehidupan seharihari.

\section{Analisis Data}

Analisis data yang digunakan dalam penelitian ini adalah analisis kuantitatif dan kualitatif.

Analisis secara kuantitatif. Hal ini dilakukan untuk menguji hipotesis dengan menggunakan analisis statistik berupa tehnik Analisis Kovarians (Anakova) 1 Jalur 1 Kovariabel. Perbedaan tingkatan depresi akibat adanya perbedaan hasil perlakuan diamati secara berulang-ulang yaitu sebelum perlakuan, setelah perlakuan, dan tindak lanjut (followup) antara kelompok eksperimen yang mendapatkan pelatihan manajemen emosi dengan kelompok kontrol. Uji efektivitas pelatihan ini dianalisis secara statistik dengan menggunakan tehnik eta-square. Semua analisis data menggunakan paket Statistical Product and Service Solution (SPSS) for Windows versi 11,5.

Analisis secara kualitatif. Analisis kualitatif dilakukan secara individual dan bertujuan untuk menjelaskan proses-proses manajemen emosi yang terjadi pada masing-masing individu. Analisis kualitatif ini mengambil sampel terhadap subjek-subjek kelompok 
eksperimen yang mewakili penurunan skor depresi tertinggi dan subjek-subjek yang mewakili penurunan skor depresi terendah atau tidak mengalami perubahan. Proses analisis data secara kualitatif dimulai dengan melakukan inspeksi visual (visual inspection) untuk melihat subjek yang mengalami perubahan skor depresi ekstrim tinggi dan yang tidak mengalami atau sedikit mengalami perubahan skor depresi. Hal ini dilakukan dengan mengolah data yang diperoleh dari observasi, wawancara yang dilakukan terhadap partisipan, data pemantauan diri partisipan dalam kelompok eksperimen selama mengikuti pelatihan manajemen emosi, data lembar-lembar kerja yang diberikan, analisis isi dari buku harian, dan data evaluasi partisipan setelah mengikuti pelatihan manajemen emosi.

\section{Hasil Penelitian}

\section{Deskripsi Partisipan}

Ada perbedaan skor depresi pada setiap pengukuran. Hal ini terlihat pada tabel di bawah ini:

Tabel 4. Perbedaan Rata-rata Skor Depresi

\begin{tabular}{lccc}
\hline \multicolumn{1}{c}{ Kelompok } & Prates & Pascates & Tindak lanjut \\
\hline Eksperimen & 21,20 & 16,30 & 14,70 \\
Kontrol & 21,10 & 21,40 & 22,10 \\
\hline
\end{tabular}

Rata-rata skor depresi pada kelompok eksperimen lebih rendah daripada rata-rata skor depresi kelompok kontrol baik pada pengukuran sesudah perlakuan maupun pengukuran tindak lanjut.

Angka pada Tabel 4 di atas menunjukkan bahwa pada kelompok eksperimen terjadi penurunan tingkat depresi yang lebih besar dibandingkan kelompok kontrol pada pengukuran segera sesudah pelatihan (post test) dan dua minggu setelah pelatihan (follow-up).

\section{Hasil Analisis Kuantitatif}

Pengujian hipotesis dilakukan dengan uji statistik, yaitu Analisis Kovarians (Anakova) 1 Jalur 1 Kovariabel untuk melihat efektivitas pelatihan manajemen emosi dalam menurunkan depresi. Skor depresi pada pengukuran sebelum pelatihan (pre-test) menjadi kovariabel. Hasil analisis data dengan Anakova terdapat pada Tabel 5. 
Tabel 5. Rangkuman Anakova

\begin{tabular}{llccccc}
\hline Pengukuran & $\begin{array}{c}\text { Variabel } \\
\text { Tergantung }\end{array}$ & JK & db & RK & F & p \\
\hline \multirow{2}{*}{ Kelompok } & Pascates & 134,796 & 1 & 134,796 & 22,750 & 0,001 \\
& Tindak lanjut & 280,358 & 1 & 280,358 & 29,089 & 0,001 \\
\hline
\end{tabular}

Tabel 5 menunjukkan ada perbedaan skor depresi yang signifikan antara kelompok eksperimen dan kelompok kontrol pada pengukuran sesudah perlakuan (post-test) dengan $\mathrm{F}=$ 22,750 dan $p=0,001(p<0,05)$. Ada perbedaan skor depresi yang signifikan antara kelompok eksperimen dan kelompok kontrol pada pengukuran tindak lanjut perlakuan (follow-up) dengan $F=29,089$ dan $p=0,001(p<0,05)$.

Selanjutnya untuk melihat penurunan depresi pada kelompok eksperimen tersebut signifikan atau tidak dilakukan analisis tambahan yaitu uji-t pada masing-masing pengukuran. Hasil analisis tersebut dapat dilihat pada tabel berikut ini:

Tabel 6. Ringkasan Hasil Uji-t Skor Depresi pada Kelompok Eksperimen

\begin{tabular}{lccc}
\hline \multicolumn{1}{c}{ Sumber } & Rerata Penurunan & $\mathrm{t}$ & $\mathrm{p}$ \\
\hline Prates - pascates & 4,9 & 6,788 & 0,001 \\
Prates - tindak lanjut & 6,5 & 5,866 & 0,001 \\
\hline
\end{tabular}

Dari Tabel 6 di atas dapat dikemukakan ada perbedaan yang signifikan antara skor depresi subjek eksperimen sebelum pelatihan (pre-test) dan segera sesudah pelatihan (posttest) dengan rerata penurunan depresi sebesar 4,9 . Hasil analisis tersebut juga menunjukkan ada perbedaan yang signifikan antara skor depresi subjek eksperimen sebelum pelatihan (pre-test) dan tindak lanjut (follow-up) dengan rerata penurunan depresi sebesar 6,5. Berdasarkan hasil di atas dapat disimpulkan bahwa skor depresi pada kelompok eksperimen yang mendapatkan pelatihan manajemen emosi menurun bila dibandingkan dengan kelompok kontrol pada pengukuran sesudah pelatihan (post-test) dan dua minggu sesudah pelatihan (follow-up). Pelatihan manajemen emosi mampu menurunkan tingkat depresi subjek pada kelompok eksperimen dari tingkatan depresi sedang menjadi depresi ringan.

Peranan intervensi pelatihan manajemen emosi dalam menurunkan depresi pada pengukuran setelah pelatihan (post-test) sebesar $57,2 \%$ sedangkan peranan intervensi pelatihan manajemen emosi pada pengukuran tindak lanjut (follow-up) sebesar $63,1 \%$.

Berdasarkan hasil analisis kuantitatif tersebut, maka dapat disimpulkan bahwa pelatihan manajemen emosi efektif untuk menurunkan depresi pada remaja korban selamat gempa bumi Yogyakarta. 


\section{Hasil analisis kualitatif}

Hasil analisis kualitatif menemukan bahwa proses manajemen emosi yang terjadi pada subjek-subjek dengan penurunan skor depresi tertinggi berbeda dengan subjek-subjek dengan penurunan skor depresi terendah. Untuk subjek dengan penurunan skor depresi tertinggi, proses manajemen emosi yang terjadi yaitu dapat mengenali emosi yang terdapat dalam dirinya dengan baik, dapat mengekspresikan emosi yang terdapat dalam dirinya secara mendalam baik secara lisan maupun melalui media tulisan, dapat merasakan manfaat langsung dari teknik relaksasi dalam mengelola emosi dan tetap menjaga kesinambungannya dengan menerapkannya dalam kehidupan sehari-hari, serta telah dapat menunjukkan adanya kemampuan mengubah emosi negatif yang ada dalam dirinya dan memperbesar munculnya emosi positif dalam dirinya. Emosi positif yang muncul antara lain adanya keyakinan dan harapan dapat meraih impian atau cita-cita dalam hidupnya.

Untuk subjek dengan penurunan skor depresi terendah, proses manajemen emosi yang terjadi yaitu dapat mengenali emosi yang terdapat dalam dirinya tetapi masih cenderung menggunakan mekanisme pertahanan diri dalam upaya mengenali emosi yang dirasakannya tersebut, mengalami kesulitan dalam mengekspresikan emosi baik secara lisan maupun tulisan, telah dapat merasakan manfaat langsung dari teknik relaksasi dalam mengelola emosi tetapi cenderung tidak menerapkannya dalam kehidupan sehari-hari, cenderung belum dapat mengubah dari emosi negatif yang dirasakannya menjadi emosi positif dalam dirinya. Subjek masih cenderung bersikap persisten, defensif, dan tertutup dalam proses manajemen emosinya.

\section{Pembahasan}

Hasil yang diperoleh dalam penelitian ini menunjukkan bahwa pelatihan manajemen emosi efektif dalam mengurangi depresi pada remaja korban selamat gempa bumi Yogyakarta. Hal ini mendukung beberapa penelitian lain yang menunjukkan adanya pengaruh positif program manajemen emosi dalam mengatasi gangguan depresi (Horowitz dan Garber, 2006). Program manajemen emosi lainnya yang pernah dilakukan antara lain yang dilakukan oleh Cloitre, dkk. (2002) mengenai pelatihan keterampilan regulasi emosi dan interpersonal pada korban PTSD, Yang dan Wang (2001) mengenai program manajemen emosi dalam meningkatkan stabilitas emosi dan hubungan interpersonal pada siswa-siswa SMK, serta Heimberg, dkk. (2002) mengenai pelatihan regulasi emosi dalam mengatasi gangguan kecemasan umum.

Keberhasilan pelatihan manajemen emosi dalam menurunkan tingkat depresi 
dipengaruhi oleh beberapa faktor penting yang menentukan dalam suatu pelatihan, yaitu modul pelatihan, trainer (yang dalam pelatihan ini selanjutnya disebut dengan fasilitator), dan karakteristik partisipan dalam pelatihan tersebut (Grieshaber, 1994). Tiga hal di atas dijelaskan dalam pembahasan berikut ini.

Pertama, modul pelatihan manajemen emosi. Penyusunan modul pelatihan dirancang secara khusus untuk mengatasi gangguan depresi dengan terlebih dahulu dilakukan proses asesmen kebutuhan pada partisipan penelitian. Metode atau teknik yang dipakai dalam modul pelatihan ini antara lain melalui permainan, ceramah, simulasi, tayangan film, presentasi, dan diskusi kelompok sehingga tidak membuat para partisipan merasa bosan atau jenuh dalam menjalani setiap sesi dalam pelatihan. Pelatihan manajemen emosi ini juga menggunakan metode pemantauan diri yang dapat berfungsi sebagai agen perubahan perilaku subjek (Kazdin, 2001). Partisipan diminta untuk memantau dan mencatat keadaan emosi yang dirasakan, deskripsi situasi atau keadaan pemicu, dan seberapa besar taraf emosi yang muncul. Pemantauan dan pencatatan ini dilakukan dengan tujuan agar subjek dapat belajar mengenali reaksi-reaksi emosi yang terdapat dalam dirinya. Pelatihan manajemen emosi yang disusun penulis ini dilakukan dengan menggunakan pendekatan kelompok. Pendekatan kelompok yang dipakai dalam pelatihan dinilai efektif dan berhasil, karena adanya faktor terapeutik pendekatan kelompok (Yalom, 1985).

Kedua, fasilitator. Pelatihan manajemen emosi ini dipandu oleh seorang fasilitator. Peran dari fasilitator adalah memimpin proses pelatihan (yaitu memberikan edukasi terkait dengan materi pelatihan manajemen emosi), memimpin proses diskusi, membantu peneliti melakukan evaluasi selama proses pelatihan, berperan sebagai model dalam menerapkan berbagai keterampilan emosi, dan berperan sebagai katalisator. Peran fasilitator di atas sesuai dengan kualifikasi fasilitator dalam memandu pelatihan ini.

Ketiga, partisipan. Keberhasilan pelatihan manajemen emosi ini juga didukung oleh antusiasme dan penerimaan yang baik dari para partisipan. Hal ini dapat dilihat dari hasil evaluasi pelatihan yang secara keseluruhan menilai pelatihan ini menarik, bagus, bermanfaat, dan menambah ilmu dengan materi-materi yang diberikannya. Sesi-sesi dalam pelatihan manajemen emosi ini juga dinilai menarik, bermanfaat, dan mudah dilakukan. Pelatihan ini terbukti efektif untuk partisipan penelitian dengan karakteristik siswa-siswa kelas 2 SMP dengan rentang usia 13-15 tahun baik laki-laki maupun perempuan dan mempunyai tingkat depresi pada taraf sedang.

Berdasarkan hasil rata-rata skor depresi kelompok eksperimen dan kelompok kontrol ditemukan adanya penurunan tingkat depresi pada kelompok eksperimen yang diberikan 
pelatihan manajemen emosi segera sesudah pelatihan (post-test) dan dua minggu setelah pelatihan (follow-up). Pelatihan manajemen emosi mampu menurunkan tingkat depresi subjek pada kelompok eksperimen dari tingkatan depresi sedang menjadi depresi ringan. Peranan intervensi pelatihan manajemen emosi dalam menurunkan depresi pada pengukuran tindak lanjut (follow-up) lebih efektif dibandingkan pengukuran pascates (posttest), yaitu sebesar $63,1 \%$. Hal ini disebabkan oleh adanya proses transfer belajar (transfer of learning process) yang telah dapat dilakukan oleh para partisipan pelatihan setelah mengikuti pelatihan manajemen emosi.

Analisis kualitatif yang dilakukan dalam penelitian ini menemukan bahwa individuindividu dengan penurunan skor depresi tertinggi menunjukkan proses manajemen emosi yang berbeda dengan individu-individu yang memiliki penurunan skor depresi terendah. Faktor-faktor yang dapat menyebabkan munculnya perbedaan proses manajemen emosi ini antara lain adalah tipe kepribadian, situasi dan kondisi yang dialami subjek, serta faktor keluarga. Individu-individu dengan penurunan skor depresi yang rendah memiliki tipe kepribadian yang cenderung tertutup sehingga fasilitator menemui kesulitan dalam mendekati atau memotivasi subjek. Keadaan subjek saat ini tidak hanya disebabkan oleh ingatan mengenai peristiwa traumatis kejadian gempa yang lalu, tetapi juga disebabkan oleh dampak bencana yang muncul yaitu adanya tanggung jawab besar yang dirasakan oleh subjek pasca kejadian gempa bumi.

Peristiwa gempa menimbulkan banyak perubahan dalam kehidupan subjek antara lain kehilangan rumah, perabotan rumah tangga, buku-buku, seragam sekolah, dan bendabenda berharga lainnya, serta adanya anggota keluarga yang meninggal atau mengalami patah tulang akibat terkena reruntuhan rumah. Keadaan subjek ini juga dipengaruhi oleh faktor keluarga. Dari hasil wawancara pada tahapan tindak lanjut (follow-up), subjek mengatakan seringkali merasakan tertekan dengan banyaknya tuntutan yang diberikan orangtua kepada subjek pasca gempa misalnya dalam hal pendidikan dengan harus belajar lebih giat lagi untuk membahagiakan orang tua. Individu-individu tersebut harus mengambil peranan untuk dapat meringankan beban keluarga misalnya dengan membantu orang tua mengerjakan pekerjaan rumah tangga atau membantu orang tuanya bekerja di sawah dengan tetap harus fokus pada pelajarannya di sekolah. Hal ini juga terkait dengan urutan kelahiran subjek dalam keluarga. Subjek dengan urutan kelahiran pertama dalam keluarga atau mempunyai jumlah saudara yang lebih sedikit membuat subjek mengemban tanggung jawab yang lebih besar.

Individu menjadikan semua tanggung jawab yang dihadapi oleh keluarganya ini 
menjadi bagian dari dirinya, sehingga cenderung mengabaikan keadaan yang terjadi atau reaksi emosi yang dialaminya. Subjek tidak mempunyai kemampuan mengatasi masalah (coping) yang efektif dalam mengatasi dampak-dampak yang muncul tersebut. Subjek menjadi cenderung bersikap persisten, defensif, dan sangat tertutup dalam menceritakan pengalaman dan mengeksplorasi emosi-emosi yang dirasakan berkaitan dengan kejadian gempa bumi. Hal ini juga menyebabkan beberapa partisipan menjadi persisten dan defensif terhadap materi-materi yang diberikan dalam pelatihan manajemen emosi.

Subjek-subjek yang cenderung bersikap persisten dan defensif dalam proses manajemen emosinya menunjukkan adanya penurunan skor depresi yang terendah. Faktorfaktor yang mendukung penurunan skor depresi terendah yang didapatkan dari proses pelatihan antara lain adanya motivasi subjek yang rendah dalam mengikuti pelatihan manajemen emosi, kurang mau terbuka dalam menceritakan pengalamannya, kurang mempunyai kepercayaan terhadap orang lain, kurang memiliki rasa ingin tahu yang besar, dan cenderung tidak mengerjakan tugas-tugas yang diberikan dengan baik.

Berdasarkan dari hasil analisis kualitatif di atas dapat disimpulkan bahwa individuindividu dengan penurunan depresi tertinggi menunjukkan proses manajemen emosi yang berbeda dengan individu-individu yang menunjukkan penurunan depresi terendah. Modul dalam penelitian ini tampaknya masih belum dapat memfasilitasi seluruh partisipan dengan baik, khususnya terhadap subjek-subjek yang cenderung bersikap persisten dan defensif. Peneliti berpendapat perlu adanya materi-materi tambahan dalam modul ini yang lebih menekankan pada beberapa hal antara lain: eksplorasi emosi terkait dengan dampak-dampak yang muncul pasca kejadian gempa bumi, dinamika kelompok, dan proses katarsis emosi pada masing-masing partisipan. Selain itu juga perlu adanya tambahan materi pelatihan yang lebih mengarahkan partisipan pada materi-materi yang lebih positif lagi misalnya peningkatan motivasi partisipan, arti penting dari sikap terbuka dalam menceritakan pengalaman, belajar mengenai kepercayaan terhadap orang lain, menumbuhkan rasa ingin tahu yang besar, dan lain-lain. Dengan adanya perbaikan pada modul pelatihan ini diharapkan dapat memfasilitasi seluruh partisipan penelitian dan dapat semakin meningkatkan efektivitas pelatihan manajemen emosi.

Peneliti juga mengalami beberapa kendala dalam menjalankan penelitian ini, yaitu pihak sekolah belum dapat terlibat secara menyeluruh dalam proses pelatihan, sehingga dalam pelaksanaan seluruhnya dilakukan oleh pihak peneliti. Hal ini yang menyebabkan keberlanjutan dari program pelatihan ini tidak dapat dilakukan. Upaya yang dapat dilakukan untuk mengatasi kendala tersebut adalah dengan mempertimbangkan adanya kemungkinan 
menjadikan pelatihan manajemen emosi ini sebagai salah satu alternatif program intervensi berbasis sekolah (school-based interventions) dalam proses selanjutnya. Intervensi berbasis sekolah merupakan salah satu bentuk program komunitas yang diterapkan dalam setting sekolah dengan mempersiapkan sekolah untuk dapat menjalankan suatu program kegiatan secara mandiri (Dalton, dkk., 2002). Beberapa hal yang dapat dipersiapkan selanjutnya antara lain melakukan koordinasi dengan pihak sekolah dalam merumuskan pelaksanaan program pelatihan, menentukan kualifikasi guru yang akan menjalankan pelatihan manajemen emosi ini, memberikan pelatihan kepada guru-guru tersebut untuk persiapan pelaksanaan pelatihan lebih lanjut, membina kerjasama dengan berbagai stakeholders terkait misalnya dengan pihak Dinas Pendidikan untuk pembahasan mengenai mekanisme pelaksanaan, dan lain-lain.

\section{Simpulan dan Rekomendasi}

\section{Simpulan}

Berdasarkan hasil penelitian yang telah dilakukan, maka dapat disimpulkan bahwa:

Hasil analisis kualitatif. Pelatihan manajemen emosi efektif untuk mengurangi depresi pada remaja korban selamat gempa bumi Yogyakarta. Hal ini terlihat dari perbedaan skor depresi yang signifikan antara kelompok eksperimen dan kelompok kontrol pada pengukuran sesudah perlakuan (post-test) dengan $F=22,750$ dan $p<0,05$. Ada perbedaan skor depresi yang signifikan antara kelompok eksperimen dan kelompok kontrol pada pengukuran tindak lanjut perlakuan (follow-up) dengan $\mathrm{F}=29,089$ dan $\mathrm{p}<0,05$. Hasil rata-rata skor depresi antara kelompok eksperimen dan kelompok kontrol menunjukkan bahwa pelatihan manajemen emosi mampu menurunkan tingkat depresi subjek dari tingkatan depresi sedang menjadi depresi ringan. Peranan intervensi pelatihan manajemen emosi dalam menurunkan depresi pada pengukuran setelah pelatihan (post-test) sebesar $57,2 \%$ sedangkan peranan intervensi pelatihan manajemen emosi pada pengukuran tindak lanjut (follow-up) sebesar $63,1 \%$.

Hasil analisis kualitatif. Ditemukan bahwa individu-individu dengan penurunan skor depresi tertinggi menunjukkan proses manajemen emosi yang berbeda dengan individuindividu yang penurunan skor depresinya terendah. Faktor-faktor yang menyebabkan perbedaan tersebut antara lain tipe kepribadian, situasi dan kondisi subjek, serta faktor keluarga. Hal inilah yang kemudian menjadi fokus perhatian untuk perbaikan penelitian lebih lanjut sehingga dapat lebih meningkatkan efektivitas pelatihan. 


\section{Rekomendasi}

Rekomendasi kepada kalangan profesional. Hasil penelitian ini menunjukkan bahwa pelatihan manajemen emosi efektif dalam mengurangi depresi pada remaja korban selamat gempa bumi Yogyakarta, sehingga dapat dijadikan sebagai salah satu intervensi psikologis dalam pengatasan depresi pada korban selamat gempa bumi. Kalangan profesional juga diharapkan dapat mempersiapkan adanya keberlanjutan program pelatihan manajemen emosi ini di sekolah sebagai salah satu intervensi berbasis sekolah (school-based interventions) dengan memberikan pelatihan kepada para guru, sehingga diharapkan nantinya pihak sekolah dapat melakukan program pelatihan ini sendiri atau juga dapat mentransfernya bagi pihak sekolah-sekolah lainnya. Selain itu pula dengan menjadikan program ini sebagai intervensi berbasis sekolah (school-based interventions) dapat memperluas kebermanfaatan program ini bagi para siswa-siswa lainnya yang juga menjadi korban gempa bumi.

Rekomendasi kepada subjek penelitian. Pelatihan manajemen emosi ini efektif untuk mengatasi depresi pada remaja korban selamat gempa bumi Yogyakarta yang berusia 13-15 tahun. Oleh karena itu diharapkan subjek penelitian tetap dapat terus mempraktekkan latihanlatihan dari materi pelatihan yang telah didapatkan dalam kehidupannya sehari-hari.

Rekomendasi untuk peneliti selanjutnya. Ada beberapa hal yang dapat diajukan untuk penelitian yang akan datang, antara lain :

1. Modul pelatihan manajemen emosi secara tertulis belum dibakukan, sehingga masih terbuka kesempatan untuk menelitinya lebih lanjut. Berdasarkan pelaksanaan pelatihan yang telah dilakukan disarankan untuk mempertimbangkan adanya materi-materi tambahan antara lain eksplorasi emosi terkait dengan dampak-dampak yang muncul pasca kejadian gempa bumi, dinamika kelompok, proses katarsis emosi pada masingmasing partisipan. Selain itu juga perlu adanya tambahan materi pelatihan yang lebih mengarahkan partisipan pada materi-materi yang lebih positif lagi. Dengan adanya perbaikan pada modul pelatihan ini diharapkan dapat memfasilitasi seluruh partisipan penelitian dan dapat semakin meningkatkan efektivitas pelatihan manajemen emosi.

2. Pada pelatihan ini pengukuran tindak lanjut (follow-up) dilakukan dua minggu setelah pelatihan berakhir. Penelitian berikutnya dapat melihat keberlangsungan efek pelatihan manajemen emosi ini dalam waktu beberapa bulan setelah pelatihan selesai dilaksanakan.

3. Pada penelitian ini, subjek yang dipakai mempunyai tingkat depresi sedang. Penelitian selanjutnya dapat melihat efektivitas pelatihan ini pada subjek dengan tingkatan depresi yang berbeda misalnya tingkatan depresi berat. 
4. Pada penelitian ini, partisipan yang dipakai adalah siswa-siswa SMP dengan rentang usia 13-15 tahun. Penelitian yang akan datang dapat melihat efektivitas pelatihan manajemen emosi pada partisipan yang berbeda misalnya pada siswa-siswa SMA.

5. Penelitian berikutnya dapat memperhatikan beberapa faktor lain yang juga mempengaruhi kecenderungan depresi misalnya faktor kepribadian, dukungan sosial, dan lain-lain.

\section{Daftar Pustaka}

Andrews, L., Harris, G., \& Howle, B. 2005. Assessing Positive and Negative Changes in The Aftermath of Adversity: Psychometric Evaluation of The Changes in The Outlook Questionnaire. PsychologicalAssessment, 17, 70-80.

Beck, A. T. 1985. Depression: Causes and Treatment. Philadelphia: University of Pennsylvania Press.

Cloitre, M., Cohen, L. R., Koenen, K. C., \& Han, H. 2002. Skills Training in Affective and Interpersonal Regulation Followed by Exposure: A Phase-Based Treatment for PTSD Related to Childhood Abuse. Journal of Consulting and Clinical Psychology, 70, 10671074.

Dalton, J. H., Elias, M. C., \& Wandersman, A. 2002. Community Psychology Linking Individuals and Communities. Australia: Wadsworth Thompson Learning, Inc.

Goldman, R. N., Pos, A. E., Greenberg, L. S., \& Korman, L. M. 2003. Emotional Processing During The Experiential Treatment of Depression. Journal of Consulting and Clinical Psychology, 71, 1007-1016.

Greenberg, M.A., \& Stone, A.A. 1992. Emotional Disclosure about Traumas and its Relation to Health: Effects of Previous Disclosure and Trauma Severity. Journal of Personality and Social Psychology, 63, 75-84.

Grieshaber, C. 1994. Step by Step Group Development. Feldafing: German Foundation for International Development, Centre for Food and Agriculture Development.

Heimberg, R. G., Mennin, D. S., Turk, C. L., \& Fresco, D. M. 2002. Applying an Emotion Regulation Framework to Integrative Approaches to Generalized Anxiety Disorder. Clinical Psychology Science and Practice, 9, 85-90.

Horowitz, J. L., \& Garber, J. 2006. The Prevention of Depressive Symptoms in Children and Adolescents: A Meta-Analytic Review. Journal of Consulting and Clinical Psychology, $74,401-415$.

Kazdin, A. 2001. Behavior Modification in Applied Settings. Sixth Edition. California: Wadsworth Thomson Learning, Inc. 
Lindsay, S. \& Powell, G. 1994. Depression Handbook of Clinical Adult. New York: New York, Inc.

Rayburn, N. R., Wenzel, S. L., Elliott, M. N., Hambarsoomians, K., Marshall, G. N., \& Tucker, J. S. 2005. Trauma, Depression, Coping, and Mental Health Service Seeking Among Impoverished Women. Journal of Consulting and Clinical Psychology, 73, 667-677.

Scott, C., \& Myers, K. K. 2002. The Emotions of Socialization and Assimilation: Learning Emotion Management at the Fire Station. Arizona: Arizona State University.

Silvia, P. A., Newman, D. L., Moffit, T. E., \& Caspi, A. 1996. Psychiatric Disorder in A Birth Cohort of Young Adults: Prevalence, Comorbidity, Clinical Significance, and New Case Insidence From Aging 11 to 21. Journal of Consulting and Clinical Psychology, 64, 352362.

Watson, J. C., Gordon, L. B., Stermac, L., Kalogerakos, F., \& Steckley, P. (2003). Comparing The Effectiveness of Process-Experiential With Cognitive-Behavioral Psychotherapy in The Treatment of Depression. Journal of Consulting and Clinical Psychology, 71, 773-781.

Yalom, I. D. 1985. The Theory and Practice of Group Psychotherapy. USA: BasicBooks.

Yang, M. K., \& Wang, G. S. 2001. The Effects of an Emotional Management Programme on The Work Emotional Stability and Interpersonal Relationships of Vocational School Students. Global Journal Australian of Engineering Education, 5, 175-184. 